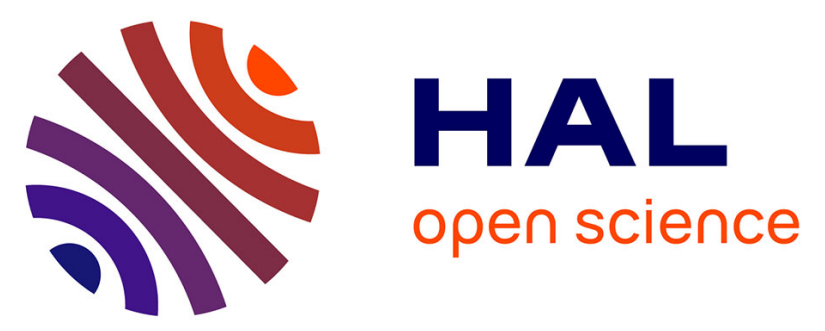

\title{
New insights into type II Germ Cell Tumor pathogenesis based on studies of patients with various forms of Disorders of Sex Development (DSD)
}

Remko Hersmus, Bertie H.C.G.M. de Leeuw, Katja P. Wolffenbuttel, Stenvert L.S. Drop, J. Wolter Oosterhuis, Martine Cools, Leendert H.J. Looijenga

\section{To cite this version:}

Remko Hersmus, Bertie H.C.G.M. de Leeuw, Katja P. Wolffenbuttel, Stenvert L.S. Drop, J. Wolter Oosterhuis, et al.. New insights into type II Germ Cell Tumor pathogenesis based on studies of patients with various forms of Disorders of Sex Development (DSD). Molecular and Cellular Endocrinology, 2008, 291 (1-2), pp.1. 10.1016/j.mce.2008.02.028 . hal-00532011

\section{HAL Id: hal-00532011 https://hal.science/hal-00532011}

Submitted on 4 Nov 2010

HAL is a multi-disciplinary open access archive for the deposit and dissemination of scientific research documents, whether they are published or not. The documents may come from teaching and research institutions in France or abroad, or from public or private research centers.
L'archive ouverte pluridisciplinaire HAL, est destinée au dépôt et à la diffusion de documents scientifiques de niveau recherche, publiés ou non, émanant des établissements d'enseignement et de recherche français ou étrangers, des laboratoires publics ou privés. 


\section{Accepted Manuscript}

Title: New insights into type II Germ Cell Tumor pathogenesis based on studies of patients with various forms of Disorders of Sex Development (DSD)

Authors: Remko Hersmus, Bertie H.C.G.M. de Leeuw, Katja P. Wolffenbuttel, Stenvert L.S. Drop, J. Wolter Oosterhuis, Martine Cools, Leendert H.J. Looijenga

PII: S0303-7207(08)00111-1

DOI: doi:10.1016/j.mce.2008.02.028

Reference: $\quad$ MCE 6836

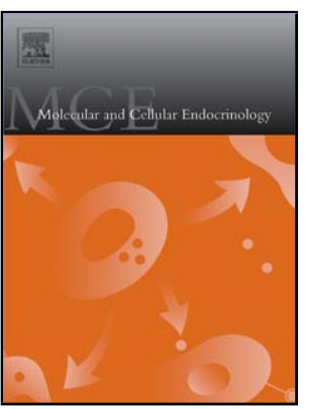

To appear in: $\quad$ Molecular and Cellular Endocrinology

Received date: 20-12-2007

Accepted date: $\quad$ 26-2-2008

Please cite this article as: Hersmus, R., de Leeuw, B.H.C.G.M., Wolffenbuttel, K.P., Drop, S.L.S., Oosterhuis, J.W., Cools, M., Looijenga, L.H.J., New insights into type II Germ Cell Tumor pathogenesis based on studies of patients with various forms of Disorders of Sex Development (DSD), Molecular and Cellular Endocrinology (2007), doi:10.1016/j.mce.2008.02.028

This is a PDF file of an unedited manuscript that has been accepted for publication. As a service to our customers we are providing this early version of the manuscript. The manuscript will undergo copyediting, typesetting, and review of the resulting proof before it is published in its final form. Please note that during the production process errors may be discovered which could affect the content, and all legal disclaimers that apply to the journal pertain. 


\section{New insights into type II Germ Cell Tumor pathogenesis based on studies of patients with various forms of Disorders of Sex Development (DSD).}

${ }^{1}$ Remko Hersmus*, ${ }^{1}$ Bertie H.C.G.M. de Leeuw*, ${ }^{2}$ Katja P. Wolffenbuttel, ${ }^{3}$ Stenvert L.S. Drop, ${ }^{1} \mathrm{~J}$. Wolter Oosterhuis, ${ }^{4}$ Martine Cools and ${ }^{1}$ Leendert H.J. Looijenga ${ }^{\#}$

Departments of ${ }^{1}$ Pathology, ${ }^{2}$ Pediatric Urology, ${ }^{3}$ Pediatric Endocrinology, Erasmus MC - University Medical Center Rotterdam, Daniel den Hoed Cancer Center, Josephine Nefkens Institute, Rotterdam The Netherlands, ${ }^{4}$ Department of Pediatric Endocrinology, University Hospital Ghent, Belgium.

${ }^{*}$ Contributed equally to the work

\#corresponding author:

Building Be, Room 430b

PO Box 1738, 3000 DR

tel.: + 31-10-7044329

fax: + 31-10-7044365

E-mail: I.looijenga@erasmusmc.nl

Financial support by grants: Erasmus MC Translational Research (RH); Dutch Cancer Society (KWF) (BdL); Research Foundation Flanders (FWO) (MC). 


\section{Abstract:}

Disorders of sex development (DSD), previously known as intersex, refer to congenital conditions in which development of chromosomal, gonadal, or anatomical sex is atypical. Patients with specific variants of this disorder have an elevated risk for the development of so-called type II germ cell cancers, i.e., the seminomatous and nonseminatous tumors, referred to as GCTs. Specifically DSD patients with gonadal dysgenesis or hypovirilization are at risk. A prerequisite for type II GCT formation is the presence of a specific part of the Y-chromosome (referred to as the GBY region), with the TSPY gene being the most likely candidate. Also the octamer binding transcription factor OCT3/4 is consistently expressed in all type II GCTs with pluripotent potential, as well as in the precursor lesions carcinoma in situ (CIS) in case of a testis and gonadoblastoma (GB) in the DSD gonad. The actual risk for malignant transformation in individual DSD patients is hard to predict, because of confusing terminology referring to the different forms of DSD, and unclear criteria for identification of the presence of malignant germ cells, especially in young patients. This is specifically due to the phenomenon of delay of germ cell maturation, which might result in over diagnosis. This review will give novel insight into the pathogenesis of the type II GCTs through the study of patients with various forms of DSD for which the underlying molecular defect is known. To allow optimal understanding of the pathogenesis of this type of cancers, first normal gonadal development, especially regarding the germ cell lineage, will be discussed, after which type II GCTs will be introduced. Subsequently, the relationship between type II 
GCTs and DSD will be described, resulting in a number of new insights into the development of the precursor lesions of these tumors. 


\section{Introduction:}

Developmental processes are a key to the complexity of multi-cellular organisms, including mammals. Studies showing how mistakes in developmental programming can lead to diseases, including tumors (benign and malignant), may be instrumental to understand the fundamental basis of the pathogenetic process(es) involved. Based on this knowledge, new approaches can be developed to prevent initiation of the mal-development and/or deal with the disease once it is formed.

Human germ cell tumors (GCTs), especially those we refer to as type II GCTs (i.e., the seminomatous and nonseminomatous tumors), are unique, because they hold the capacity to develop into any cell type of the body, as well as extra-embryonic lineages (Looijenga et al., 2002; Oosterhuis et al., 2005). In addition, it was recently demonstrated that they can also generate the germ cell lineage (Honecker et al., 2006). In other words, type II GCTs are really totipotent, which is likely related to their cell of origin, the primordial germ cell (PGC)/gonocyte. Therefore, in our view, investigation of these malignancies will shed light on regulation of processes like proliferation and differentiation, leading to normal or aberrant embryogenesis. A comprehensive study of these tumors, and specifically a detailed comparison with normal germ cell development as well as embryogenesis will allow elucidation of the relevant pathogenetic mechanisms leading to malignancy. Vice versa, such an experimental set up will lead to new insight into normal development. A selected number of these aspects will be discussed in this review, particularly regarding information obtained from multidisciplinary studies of patients with DSD, previously referred to as intersex. Moreover, a 
number of likely informative lines for future studies in this context will be proposed.

\section{Normal germ cell development before entrance into the gonad:}

The embryonic stem cells that will form the germ cell lineage (i.e., resulting in mature germ cells, spermatozoa in males and oocytes in females), also called primordial germ cells (PGCs), are first recognised as a separate entity (based on various markers like alkaline phosphatase (AP) and OCT3/4 (also known as POU5F1)) in the mouse at day 6.5 post coitum (weeks 5-6 gestational age in humans) (McLaren. 2003). At this time, these cells separate from the proximal epiblast and start to migrate through the hindgut to the genital ridge. During migration these cells undergo extensive rounds of proliferation. Amongst others, the stem cell factor (SCF) - C-KIT pathway is crucial in this process (Donovan. 1994). PGCs are positive for the receptor, and the SCF will function as a chemo-attractant, leading the cells to the genital ridge, their final destination. This signalling pathway has various functions, including survival by preventing induction of apoptosis (Tu et al., 2007). Interestingly, disturbances in this signalling pathway result in various anomalies, including abnormal migration of PGCs, possibly leading to infertility. The absence of SCF in extragonadal sites induces apoptosis of miss-migrated germ cells (Runyan et al., 2006). Besides migration, PGCs undergo a process highly specific for the germ cell lineage, called epigenetic reprogramming (Hajkova et al., 2002). This is a requirement to allow these cells to transfer capacity of pluripotency to the next generation. Important to remember in this context is the fact that these cells are themselves not 
pluripotent, but they are able to transfer pluripotency to the next generation, which is crucial for the continuation of the species. Pluripotency is, amongst others, related to specific activity of a number of genes depending on their parental origin, known as genomic imprinting (Surani. 2001). The status of genomic imprinting, e.g. biparental, erased and finally uniparental, is reflecting the germ cell maturation status as well as sex lineage (paternal or maternal). PGCs that arrive at the genital ridge are called gonocytes, although they can not be distinguished from PGCs based on morphology or on marker expression. Gonocytes have a status of erased genomic imprinting, i.e. they have lost their parental specificity of imprinted genes, related to a demethylated genome (Hajkova et al., 2002).

\section{Normal male versus female development:}

In the process of male or female sex formation, different levels can be distinguished, which are consecutive and determinant in the final outcome. The process starts with the chromosomal sex, in mammals due to either the constitution of $\mathrm{XY}$ (male) or $\mathrm{XX}$ (female). In non-mammalian organisms various other sex-determining systems are functional, which will not be discussed here, because they have been extensively presented elsewhere (Schartl. 2004). The chromosomal sex normally determines gonadal sex, i.e., either testis or ovary. The decision about the final sex determination of an individual (male or female) is primarily made at the gonadal ridge when the germ cells have entered after their migration from the proximal epiblast. In normal developing males, this is due to induction of expression of a specific gene, $S R Y$ (also known as testis determining factor), expressed in the stromal 
cells of the gonad (Wilhelm et al., 2007), for review). This gene is encoded on the pseudo-autosomal region of the short arm of the $Y$ chromosome (Yp). If sufficient amounts of SRY are formed in the proper cells at the right time, amongst others depending on the stabilizing effect of a specific splice variant of the WT1 gene (+KTS) (Hammes et al., 2001), this results in induction of expression of the transcription factor SOX9. Stable SOX9 expression in turn leads to a cascade of signal transduction ending in differentiation of the stromal cells into Sertoli cells (Polanco et al., 2007). Subsequently, the next step in the process of sex differentiation, i.e. the phenotypic sex (Wilhelm et al., 2006, for review), is initiated, depending on the development of functional Sertoli cells, and later on Leydig cells, in males, and their counterparts granulosa - and theca cells, in females. Processes beyond sex determination will not be discussed in this review, although a number of relevant mechanisms have been identified which are involved in male development. These include the delay of meiosis initiation by retinoic acid (RA) involving pathways (Bowles et al., 2006; Koubova et al., 2006), resolution of Mullerian structures after expression of anti-Mullerian hormone $(\mathrm{AMH}$, also called Mullerian inhibiting substance: MIS) by Sertoli cells (Josso et al., 1998), and the descent of the testicles into the scrotum (Toppari et al., 2007) for instance. In the absence of proper SRY expression, either by absence of the gene (in case of a deletion), or by inactivating mutations, the initial cascade does not occur. Therefore, stromal cells will not differentiate into Sertoli cells, but will embark on the female pathway. In other words, these stromal cells are bipotential in origin, and are able to generate either Sertoli cells (during initiation of male development) or granulosa cells (during initiation of female 
development). In the absence of Sertoli cell formation, the female differentiation pathway will be followed and a phenotypic female will eventually develop. However, it has become clear that the female developmental pathway is not a default system in itself, as was originally thought. It requires the activation of a number of genes, including FOXL2 and WNT4. Double knockout mice for these two genes result in testis development in spite of a XX sex chromosomal constitution (Ottolenghi et al., 2007). These insights into normal sex determination must be kept in mind when searching for explanations for the various forms of DSD (see below).

Based on normal male and female development, the pattern of genomic imprinting of the germ cells will be determined; the erased PGCs will gain a fully maternal pattern of genomic imprinting in an ovarian environment, and a paternal pattern in a testicular environment (Allegrucci et al., 2005). In contrast to the female situation, which is characterized by the presence of meiotic oocytes from the post-partum time onwards, full spermatogenesis starting from spermatogonia is only initiated after puberty. For this process, the hormone testosterone is of crucial importance (De Gendt et al., 2004). It is formed by Leydig cells in the testis, and acts via the androgen receptor (AR), which is present on Sertoli cells, but most likely not on cells belonging to the germ cell lineage (Suarez-Quian et al., 1999). It is important to realize that both oocytes and spermatogonia, during normal development lose their embryonic characteristics, including expression of AP, OCT3/4 and C-KIT.

\section{Classification of human GCTs:}


Traditionally, GCTs are classified based on their histological composition. This results in the different variants of teratoma (somatic differentiation), yolk sac tumor and choriocarcinoma (extra-embryonic differentiation), and embryonal carcinoma (stem cell component, as well as seminomatous tumors (subdivided amongst others into classic and spermatocytic seminoma). The classical seminomas of the ovary are called dysgerminomas (as are germinomas of the brain, which will not be discussed here). However, this classification system does not take into account the underlying differences in the pathogenesis of these tumors, which complicates clinical treatment as well as identification of pathogenetic mechanisms. Therefore, we proposed an alternative classification system, in which five types of GCTs are identified, referred to as I to V (Oosterhuis et al., 2005; Looijenga et al., 2002). These are summarized in Table 1. One of the parameters on which this classification is based is the pattern of genomic imprinting. For the purpose of this review, only the type II GCTs are of interest, and will be discussed in more detail below.

\section{Testicular type II GCTs:}

\section{Epidemiology and histology:}

The type II GCTs of the testis, named testicular germ cell tumors (TGCTs), account for up to $60 \%$ of all malignancies diagnosed in men between 20 to 40 years of age (Ulbright. 1993). An annual increase in incidence of $3-6 \%$ in Caucasian populations is observed in recent decades. About $50 \%$ of TGCTs are seminomas and $40 \%$ consist of nonseminomas, the rest are those containing both components, referred to as combined tumors. 
The median age of patients with seminoma is 10 years higher than that of patients with nonseminoma (35 versus 25 years), the combined tumors present at an intermediate age. Seminomas are homogenous tumors in which the cells resemble PGCs/gonocytes. The nonseminomas can be composed of different elements: embryonal carcinoma (stem cell component), the somatically differentiated teratoma component, yolk sac tumor and choriocarcinoma which represent the extraembryonic differentiation component. Embryonal carcinoma cells can differentiate into the other histologies and are in fact the pluripotent stem cells of nonseminomas (Andrews et al., 1996).

\section{Precursor lesion of the testis:}

The precursor lesion for all TGCTs is the so called carcinoma in situ (CIS) (Skakkebæk. 1972), sometimes referred to as intratubular germ cell neoplasia unclassified (Gondos et al., 1983) and testicular intraepithelial neoplasia (Loy et al., 1990). CIS cells are located at the basement membrane of the seminiferous tubules in close connection with the Sertoli cells in adult testis, and are often present in the adjacent parenchyma of invasive TGCTs (Jacobsen et al., 1981; Oosterhuis et al., 2003). In the male Caucasian population the incidence of $\mathrm{CIS}$ is similar to the lifetime risk of developing a TGCT and all patients with this lesion will eventually develop an invasive TGCT. CIS, as seminoma (see above), represents the malignant counterpart of an embryonic germ cell, most likely a PGC/gonocyte. This is supported by immunohistochemical characteristics like expression of PLAP, c-KIT and OCT3/4 (Almstrup et al., 2005; Honecker et al., 2004), CIS cells also 
phenotypically and ultrastructurally resemble PGCs (Gondos. 1993), and epidemiological data suggest that the initiating event of TGCTs occurs during the fetal period (Møller. 1989). Moreover, both CIS cells and PGCs show an erased pattern of genomic imprinting (Looijenga et al., 1998), and telomerase activity is present (Albanell et al., 1999). The nature of the risk factors for TGCTs, familial predisposition, a previous TGCT, cryptorchidism, infertility and various forms of DSD (Skakkebaek et al., 1998), further support the model that the initiating step in the pathogenesis of this cancer occurs during embryonal development. CIS, present in the adjacent parenchyma of invasive TGCTs, has the same ploidy as seminoma (De Graaff et al., 1992). The chromosomal constitution of CIS cells shows an overall similar pattern of gains and losses as are present in the invasive tumors, although in CIS loss of parts of chromosomes 4 and 13, and gain of $2 p$ are more frequently found. Most importantly gain of $12 p$ is not consistently found in CIS, which indicates that over-representation of $12 p$ is established during progression from preinvasive to invasive behaviour (Rosenberg et al., 2000; Summersgill et al., 2001). The idea that genes on $12 p$ are involved in Sertoli cell independent/invasive growth of the tumor cells is tempting. Of interest in this context is the finding that genes on $12 p$ can be up regulated by TSPY (see below) (Li et al., 2007a). Moreover, human embryonic stem (ES) cell lines show gain of chromosome 12 (and 12p) during continuous (semi-solid) in vitro culturing (Draper et al., 2003), which underlines the survival/growth advantage of pluripotent cells with over-representation of this genomic fragment. Interestingly, this could be related to the idea that gain of $12 p$ is supportive for seminoma-like cells to survive outside their niche created by the Sertoli cells. 
Testicular dysgenesis syndrome:

The testicular dysgenesis syndrome (TDS) hypothesis (Skakkebæk et al., 2001), proposes that germ cells not properly nourished by Sertoli cells during fetal gonadogenesis undergo a delay in there maturation, resulting in an increased risk for subfertility and GCT formation. This model suggests that in various apparently unrelated conditions, such as certain conditions caused by chromosomal aberrations (e.g., trisomy 21), the exposure of the male fetus to xeno-estrogens and anti-androgens, and DSD, the developmental delay of germ cells is the common underlying mechanism.

\section{OCT3/4, biology and diagnostic marker}

The octamer binding transcription factor OCT3/4 is consistently and specifically expressed in all GCTs with pluripotent potential, as well as in the neoplastic precursor lesions $\mathrm{CIS}$ in testis and gonadoblastoma (GB) in the DSD gonad (Cheng et al., 2007; De Jong et al., 2005; Looijenga et al., 2003). OCT3/4 is highly expressed during the earliest stages of embryogenesis and in ES cells. In the early embryo after the blastocyst stage OCT3/4 is quickly repressed and becomes confined to the germ cell lineage (Anderson et al., 2000; Rosner et al., 1990). Loss of OCT3/4 expression in PGCs leads to apoptosis (Kehler et al., 2004), hence it is hypothesized that OCT3/4 is required for survival of PGCs. The level of expression of OCT3/4 in ES cellderived tumors in mice is highly correlated with the formation and aggressive properties of these tumors (Gidekel et al., 2003). These data suggests that aberrant expression of OCT3/4 in GCTs might be relevant to the development 
and oncogenic potential of these tumors. Besides the proven expression of OCT3/4 in ES cells, EC cells and PGCs, an increasing number of articles have recently been published reporting OCT3/4 expression in normal adult tissues, various tumors and cell lines. This interest in OCT3/4 has been triggered by the concept of adult stem cells. However, multiple pseudogenes for OCT3/4 exist and all studies so far have used non-specific primers that detect transcripts from both the OCT3/4 gene as well as from pseudogenes (De Jong et al., 2006; Zangrossi et al., 2007); (Liedtke et al., 2007). Recently a specific primer set for OCT3/4 was developed (de Jong et al., 2007). Claims of OCT3/4 expression in somatic cells have to be interpreted with care, since from studies of murine embryogenesis it is known that at $8.5 \mathrm{dpc}$ only the migrating PGCs are positive for OCT3/4, and PGCs that fail to reach the genital ridge go into apoptosis. There are no indications that there remain OCT3/4 positive cells in differentiating tissues during human embryogenesis. Moreover, recently it was shown that OCT3/4 does not play a role in mouse somatic stem cell renewal (Ledford. 2007; Lengner et al., 2007).

\section{Type // GCTs and DSD:}

GB arises in the dysgenetic gonads of DSD patients with a part of the Y chromosome. In 1987 Page postulated the hypothesis that a gene on the $Y$ chromosome (gonadoblastoma locus on the $\mathrm{Y}$ chromosome, GBY) may act as an oncogene in the context of a dysgenetic gonad (Page. 1987). Later the GBY susceptibility region was sub-localized to a region around the centromere of the $\mathrm{Y}$ chromosome. The most likely candidate gene in this region is TSPY. The TSPY protein is expressed in spermatogonia of the adult 
male, and is thought to be related to their mitotic proliferation (Schnieders et al., 1996). In the fetal gonad TSPY protein is expressed at a constant level (Honecker et al., 2004). However TSPY protein becomes more abundant compared to both normal embryonic and adult testis, in CIS, GB and sporadically in seminoma (Lau et al., 2000). TSPY is homologous to SET/NAP proteins, which play a role in nucleosome assembly and chromatin remodelling (Wagner et al., 2006). Next to some pseudogenes, also a functional $X$ chromosomal homolog of TSPY exists in humans (called TSPYlike 2 or TSPX, DENTT, hCINAP, CDA1, se20-4), which, in contrast to TSPY, is widely expressed and plays a role in growth arrest, TGFbeta1 signalling and regulates growth and differentiation of the intracellular parasite toxoplasma gondii (Chai et al., 2001; Ozbun et al., 2005; Radke et al., 2006). One of the TSPY pseudogenes has been found to be mutated in a family with (among others) male to female sex reversal (Puffenberger et al., 2004).TSPY has been shown to influence expression of genes on 12p (see above) ( $\mathrm{Li}$ et al., 2007a), and genes associated to cell cycling when transfected into HELA cells or NIH3T3 (Oram et al., 2006). It can be hypothesized that germ cells residing in an unfavourable environment, like in the case of TDS and DSD, can survive and proliferate due to prolonged expression of OCT3/4 and increased expression of TSPY.

\section{Disturbances in male versus female development, DSD.}

The physiological process of male and female development can be miss-regulated at different levels. A summary of the normal process is summarized in Figure $1 \mathrm{~A}$. Figure 1B, shows an overview of the currently 
characterized mutations and chromosomal abnormalities that are known to effect GCT risk and are which associated with DSD. This figure is not meant to represent the full spectrum of disturbances related to gonadal development, but offers some well defined examples. Previously DSD disorders were referred to as intersex. As indicated, DSD is defined as congenital conditions in which development of chromosomal, gonadal, or anatomical sex is atypical.

Many different causes may lead to DSD, varying from mutations in genes encoding proteins that play a role in the different developmental programs and cascades (like SRY, but also the AR for instance), chromosomal imbalances (of sex chromosomes in Turner syndrome $(45, \mathrm{X} 0)$, and various forms of mosaicisms) and, in other organisms than man at least, environmental influences. A consensus meeting was held in Chicago in 2005, in which it was decided that all patients with DSD will be classified based on the chromosomal constitution (i.e., karyotyping) of peripheral leukocytes. The classification system is summarized in Table 2. Although this system, like every other system, has limitations, it at least gives clarity regarding a number of issues, and prevents misunderstanding due to different terminologies used.

For some of the disorders, like $46, \mathrm{XX}$ males, in which the SRY gene is translocated to one of the $\mathrm{X}$ chromosomes, the mechanism of disturbance is easily explained. An other example are $46, X Y$ females, in which no functional SRY is present due to a deletion or an inactivating mutation (Hawkins. 1993). Other examples are: 9p-deletions (haplo-insufficiency of DMRT1) (Raymond et al., 1999) and $D A X-1$ duplication in $46, X Y$ females, which results in suppression of the SRY pathway (Swain et al., 1998). However, the mechanistic basis for most of the variants of DSD remains unexplained. This 
is further complicated by the fact that a single genetic abnormality can give a heterogeneous phenotype. This is for example found in Frasier syndrome patients. These patients have the characteristic splice mutation in intron 9 of the WT1 gene, which results in less formation of the +KTS form (Barbaux et al., 1997), leading to less SRY protein, and a diminished induction of SOX9 (Hammes et al., 2001). Most of these patients are 46,XY sex reversed females (with GB, see below), however phenotypical males with testis (and CIS, see below) have been reported as well.

A heterogeneous pattern (see Figure $1 \mathrm{~B}$ ) is also found in patients with a mosaic constitution of their sex chromosomes, which theoretically might be easily explained. However, recent findings indicate that the exact basis for this heterogeneity of either ovarian or testis development is not elucidated, and is not simply due to the predominant presence of the $\mathrm{Y}$ chromosome containing cells in the testicular area. A correlation between testicular differentiation and the percentage of $Y$ chromosome positive cells was suggested in $X X<->X Y$ chimeric mouse models, in which it was found that if the gonad contains less than 30\% Y-positive cells, it develops as an ovary (Palmer et al., 1991). At first this model seemed to be confirmed in humans (Reddy et al., 1998). However a study on a larger sample series done by us reveals that there is no direct correlation between the gonadal differentiation pattern and the presence of the $\mathrm{Y}$ chromosome (Cools et al., 2007).

It seems that in mosaic patients the timing, presence of a threshold level, and sufficient density of the SRY signal to activate the downstream cascade (especially the expression of SOX9) is important in determining the 
fate of the bipotential gonad (Veitia et al., 2001; Wilhelm et al., 2007). The possible role of prostaglandin in this process is under investigation.

\section{Germ cell tumor development in patients with various forms of DSD:}

Besides cryptorchidism, familial predisposition, in(sub)fertility and birth weight, DSD is also a significant risk factor for type II GCTs. This is relevant

for a number of reasons. For sure, it allows identification of selected groups of individuals for early diagnosis, but moreover, it also might be helpful to elucidate the underlying pathogenetic mechanisms. Specific variants of DSD (especially in patients with gonadal dysgenesis and hypovirilization) are related to an increased risk for type II GCTs (reviewed in (Cools et al., 2006a). Gonadal dysgenesis can be defined as an incomplete or defective formation of the gonads, as a result of a disturbed process of the migration of the germ cells and/or their correct organization in the fetal gonadal ridge. Hypovirilization is caused by errors in testosterone biosynthesis, by testicular unresponsiveness to stimulation by the pituitary, or by defects in androgen dependent target tissues (Grumbach et al., 2003). Based on careful literature searches, a number of conclusions can be drawn regarding the risk of type II GCTs in DSD patients. These include the significantly lower risk for GCTs in patients with CAIS compared to PAIS. This is likely due to apoptotic cell death of germ cells in CAIS patients (Hannema et al., 2006). The risk of cancer in the PAIS patients is influenced by the anatomical localization of the gonad, being the highest in abdominal sites, and the lowest in scrotal localization. Patients with ovo-testicular DSD, of which the gonads mostly consist of welldifferentiated ovarian and testicular tissue, have a low risk for type II GCTs. 
Data regarding the prevalence of GCTs in patients with $17 \beta-\mathrm{HSD}$ deficiency, Leydig cell hypoplasia, and specific gene mutations is very limited or absent. The presence of the GBY region, possibly to be substituted by the TSPY gene and/or protein (see above), in the gonads should always be ruled out in the presence of dysgenetic testes in $46, X X$ males or patients with $45, X / 46, X Y p$ or Yq mosaicism, this in light of its suspected role in the development of GCTs (see above).

The use of a uniform classification system of the various forms of DSD will hopefully shed light on the actual risk for malignant transformation of germ cells in the different DSD subgroups, which might result in a more conservative approach of gonadectomy in some patients. The benefits may include physiological induction of puberty and even fertility. To allow such a change in clinical decision-making, it is needed to characterize the germ cells in DSD patients in detail, to determine their stage of maturation and characteristics of malignant transformation. Such a screen requires a large series of well-described patients with the various forms of DSD. Because of the rareness of DSD in the general population, international collaborative studies, including pathology review of the gonads if available, using well described criteria, will be needed to acquire the numbers of patients allowing investigations of sufficient power.

\section{Possible overdiagnosis of malignant germ cells due to delay of maturation}

One of the difficulties in the diagnosis of malignant germ cells is that the diagnostic markers used are normally present in embryonic germ cells. 
This would not have been problematic if germ cells would normally mature in the gonads of patients with DSD. However, this is not always the case, especially not in patients with hypovirilization and gonadal dysgenesis. In these patients, germ cells may undergo delayed maturation, which results in a more prolonged expression of embryonic markers. This may result in overdiagnosis of malignant cells.

Overall this is a problem in young children. This notion was supported by studies of embryonic gonads of patients with trisomy 21 , amongst others (Cools et al., 2006b). Specifically delay of germ cell maturation was found in very young male patients, whereas in older patients, germ cells had lost embryonic marker expression. Careful analysis of undervirilization patients identified a number of criteria that can be used to define malignant germ cells more precisely. These include the location of the OCT3/4 positive germ cells, either at the membrane or central in the seminiferous tubule, and the distribution through the testis (Cools et al., 2005). However, identification of a marker that is absolutely specific for malignant germ cells would be very helpful for diagnostic purposes.

\section{New insight into the precursor of type II GCTs in DSD patients:}

Although information on the occurrence of type II GCTs in patients with DSD is still limited, careful analysis of published results is revealing novel insights. Such a screen of published data has been performed, of which the most important findings are represented in Figure 1B. The extent to which normal male developmental characteristics have been found in DSD patient gonads is based on patients for whom the exact mutation is known. The 
corresponding clinical syndromes of such patients are indicated to allow a link to previous publications using previous classification. However, when possible, this information was translated to the new DSD classification system. Again, Figure 1B is not representing a complete picture, but is meant to unravel a number of intriguing correlations between the underlying genetic defect and the risk for the development and type of precursor of type II GCTs. Moreover, because of the incompleteness of understanding the mechanism of sex determination, the presented scheme is, by definition, a simplification. The heterogeneity of the histological composition of the gonads in the various forms of DSD is visualized by bars.

When Figure 1B is analyzed in detail, a number of relevant conclusions can be drawn regarding the precursor lesion. These include: I) a high risk of GB is found when sex determination is disrupted in an early stage of Sertoli cell differentiation (due to abnormalities in SRY, SOX9, WT1 intron 9). It must be remembered that GB can only be formed in the presence of the GBY region of the $\mathrm{Y}$ chromosome. Early Sertoli cell development is also disturbed patients with $45, \mathrm{XO} ; 46, \mathrm{XY}$ mosaicism, who also carry a high risk to develop GB as precursor lesion The same is true for patients with $9 p$ deletions, likely related to the loss of $D M R T 1$. In conclusion, GB is found in patients that lack a certain level of Sertoli cell development. Careful histological analysis of gonadal tissue of DSD patients revealed that undifferentiated gonadal tissue (UGT) is the most likely precursor stage of GB (Cools et al., 2006c). Identification of this stage allows better diagnosis and further elucidation of the pathogenetic pathway(s); II) defects occurring later in gonadal development, like for instance $17 \beta$ HSD insufficiency and AR mutants 
(predominantly PAIS), results in enhanced risk of CIS as precursor, as can be found in males without any form of DSD as defined in this review (e.g. in simple cryptorchidism), albeit with a much lower incidence.

\section{Continuum between testicular CIS-undifferentiated gonadal tissue-GB-} invasive type II GCTs:

It has been indicated that GB and CIS are fundamentally different (Jørgensen et al., 1997; Slowikowska-Hilczer et al., 2003). We will summarize a number of arguments to support the model that this is not the case, and that GB and CIS are in fact a continuum, of which the phenotypic presentation is determined by the micro-environment, i.e., the level of virilization.

The similar types of invasive GCTs that can progress from it demonstrate the pathogenetic link between GB and CIS. In fact, all variants of invasive type II GCTs can (next to CIS) also be found associated with GB. That dysgerminomas (associated with GB) and seminomas (associated with CIS) are highly similar was recently shown using mRNA and microRNA expression profiling (Looijenga et al., 2006; Gillis et al., 2007). This is in line with previous observations that these tumors are similar with regard to the expression of immunohistochemical markers, e.g. OCT3/4 (POU5F1), c-KIT, and alkaline phosphatase, as well as chromosomal constitution (i.e., gain of 12p). These observations support the hypothesis that these tumors are in fact the same, which might be better represented by a modified nomenclature. The fact that DSD gonads predominantly contain dysgerminoma instead of the various nonseminomas is likely related to the anatomical localization of the gonad, and not due to a difference between GB and CIS. This is 
supported by the observation that intra-abdominal testes also more frequently develop seminoma than the various forms of nonseminoma (Ogunbiyi et al., 1996) .

An interesting question is why a GB is formed in some patients and CIS in others. We hypothesize that this is due to the specific microenvironment, especially the absence of functional Sertoli cells, leading to a female development. In other words, CIS can only be formed at a certain level of testicular development. Thus, GB and CIS are simply two variants of the same defect. If this is true, it is likely that a pathologist because of the absence of obvious Sertoli cell differentiation will classify a lesion as a GB, and that the same lesion will be classified as CIS in a context where Sertoli cells are identified. This is indeed the case. The criteria used by a pathologist to classify a GB are based on phenotypical environmental characteristics. A mixture of immature germ cells and stromal cells is diagnosed as GB, when found in the context of ovarian stroma. This is nicely illustrated in a Frasier syndrome patient diagnosed in our institute. Most Frasier patients (characterized by an intron 9 WT1 mutation), as discussed above, are sex reversed 46,XY females with streak gonads eventually developing GB (Love et al., 2006). However, they can also present as males with ambiguous genitalia in which a CIS lesion has developed (Schumacher et al., in press). In addition, we found that even CIS and GB can occur within a single gonad of such a patient (see Figure 2). Based on these and similar observations, and independently reported in literature (Li et al., 2007b), we conclude that indeed a continuum exists between GB and CIS. 
However, there may be differences in DNA ploidy of GB and dysgerminoma versus CIS and seminoma (the latter two being consistently polyploid) (Kildal et al., 2003). This needs further investigation. Hence, it would be of interest to investigate the genetic defects and phenotypical characteristics of the gonad in which both CIS and GB is identified.

\section{Future implications and studies to be initiated:}

An important question that remains to be answered is which forces direct the evolution from developmental delay towards tumor development? Which factors determine the nurturing qualities, for the germ cells, in delayed structures? If CIS and GB represent indeed the same entity, but in a different environment, than what do they have in common that may explain the high tumor risk? How does the lack of Sertoli cell development play a role in the malignant transformation of the germ cells? Prevention of meiosis is likely essential for type II GCT development in the context of both female and male development. What are the crucial factors involved in maintaining the germ cells in an undifferentiated and possibly proliferative state and (how) can we manipulate them? Are there similarities between the effects of endocrine disruptors in the TDS that Skakkebaek proposed and in DSD in such a way that it could have implications for a much larger population than the patients with gonadal dysgenesis?

\section{Take home message}

In conclusion it can be said that the comparison of normal and aberrant development associated with type II GCTs leads to new insights in the 
mechanisms involved in tumor formation. The aberrant expression of normal developmental markers in these tumors and in DSD gonads, provides an insight into arrested development, which otherwise would be difficult to gain. However, it should be kept in mind that tumors may differ from normal development and such hypotheses need to be checked in the normal development of the gonads. 


\section{References.}

Albanell, J.,Bosl, G.J.,Reuter, V.E.,Engelhardt, M.,Franco, S.,Moore, M.A.Dmitrovsky, E., 1999. Telomerase activity in germ cell cancers and mature teratomas. J Natl Cancer Inst. 91, 1321-1326.

Allegrucci, C.,Thurston, A.,Lucas, E.Young, L., 2005. Epigenetics and the germline. Reproduction. 129, 137-149.

Almstrup, K.,Ottesen, A.M.,Sonne, S.B.,Hoei-Hansen, C.E.,Leffers, H.,Rajpert-De Meyts, E.Skakkebaek, N.E., 2005. Genomic and gene expression signature of the pre-invasive testicular carcinoma in situ. Cell Tissue Res.

Anderson, R.,Copeland, T.K.,Scholer, H.,Heasman, J.Wylie, C., 2000. The onset of germ cell migration in the mouse embryo. Mech Dev. 91, 6168.

Andrews, P.W.,Casper, J.,Damjanov, I.,Duggan-Keen, M.,Giwercman, A.,Hata, J.-i., Von Keitz, A.,Looijenga, L.H.J.,Oosterhuis, J.W.,Pera, M.,Sawada, M.,Schmoll, H.-J.,Skakkebæk, N.E.,Van Putten, W.Stern, P., 1996. A comparative analysis of cell surface antigens expressed by cell lines derived from human germ cell tumors. Int J Cancer. 66, 806816.

Barbaux, S.,Niaudet, P.,Gubler, M.C.,Grunfeld, J.P.,Jaubert, F.,Kuttenn, F.,Fekete, C.N.,Souleyreau-Therville, N., Thibaud, E.,Fellous, M.McEIreavey, K., 1997. Donor splice-site mutations in WT1 are responsible for Frasier syndrome. Nat Genet. 17, 467-470.

Bowles, J.,Knight, D.,Smith, C.,Wilhelm, D.,Richman, J.,Mamiya, S.,Yashiro, K.,Chawengsaksophak, K.,Wilson, M.J.,Rossant, J.,Hamada, H.Koopman, P., 2006. Retinoid signaling determines germ cell fate in mice. Science. 312, 596-600.

Chai, Z.,Sarcevic, B.,Mawson, A.Toh, B.H., 2001. SET-related cell division autoantigen-1 (CDA1) arrests cell growth. J Biol Chem. 276, 3366533674.

Cheng, L.,Sung, M.T.,Cossu-Rocca, P.,Jones, T.,Maclennan, G.,De Jong, J.,Lopez-Beltran, A.,Montironi, R.Looijenga, L., 2007. OCT4: biological functions and clinical applications as a marker of germ cell neoplasia. J Pathol. 211, 1-9.

Cools, M.,Boter, M., van Gurp, R.,Stoop, H.,Poddighe, P.,Lau, Y.F.,Drop, S.L.,Wolffenbuttel, K.P.Looijenga, L.H., 2007. Impact of the Ycontaining cell line on histological differentiation patterns in dysgenetic gonads. Clin Endocrinol (Oxf). 67, 184-192.

Cools, M.,Drop, S.L.,Wolffenbuttel, K.P.,Oosterhuis, J.W.Looijenga, L.H., 2006a. Germ cell tumors in the intersex gonad: Old paths, new directions, moving frontiers. Endocr Rev. 27, 468-484.

Cools, M.,Honecker, F.,Stoop, H.,Veltman, J.D.,De Krijger, R.R.,Steyerberg, E.,Wolffenbuttel, K.P.,Bokemeyer, C.,Lau, Y.,Drop, S.L.S.Looijenga, L., .H.J., 2006b. Maturation delay of germ cells in trisomy 21 fetuses results in increase risk for the development of testicular germ cell tumors. Hum Pathol. 37, 101-111.

Cools, M.,Stoop, H.,Kersemaekers, A.M.,Drop, S.L.,Wolffenbuttel, K.P.,Bourguignon, J.P.,Slowikowska-Hilczer, J.,Kula, K.,Faradz, S.M.,Oosterhuis, J.W.Looijenga, L.H., 2006c. Gonadoblastoma arising 
in undifferentiated gonadal tissue within dysgenetic gonads. J Clin Endocrinol Metab. 91, 2404-2413.

Cools, M.,van Aerde, K.,Kersemaekers, A.M.,Boter, M.,Drop,

S.L.,Wolffenbuttel, K.P.,Steyerberg, E.W.,Oosterhuis, J.W.Looijenga, L.H., 2005. Morphological and immunohistochemical differences between gonadal maturation delay and early germ cell neoplasia in patients with undervirilization syndromes. J Clin Endocrinol Metab. 90, 5295-5303.

De Gendt, K.,Swinnen, J.V.,Saunders, P.T.,Schoonjans, L.,Dewerchin, M.,Devos, A., Tan, K.,Atanassova, N.,Claessens, F.,Lecureuil, C.,Heyns, W.,Carmeliet, P.,Guillou, F.,Sharpe, R.M.Verhoeven, G., 2004. A Sertoli cell-selective knockout of the androgen receptor causes spermatogenic arrest in meiosis. Proc Natl Acad Sci U S A. 101, 13271332.

De Graaff, W.E.,Oosterhuis, J.W.,De Jong, B.,Dam, A.,Van Putten, W.L.J.,Castedo, S.M.M.J.,Sleijfer, D.T.Schraffordt Koops, H., 1992. Ploidy of testicular carcinoma in situ. Lab Invest. 66, 166-168.

De Jong, J.Looijenga, L.H.J., 2006. Stem cell marker OCT3/4 in tumor biology and germ cell tumor diagnostics: history and future. OCT3/4 in oncogenesis. Crit Rev Oncog. 12(3-4), 171-203.

de Jong, J.,Stoop, H., Gillis, A.J.,Hersmus, R.,van Gurp, R.J.,van de Geijn, G.J.,van Drunen, E.,Beverloo, H.B.,Schneider, D.T.,Sherlock, J.K.,Baeten, J.,Kitazawa, S., van Zoelen, E.J.,van Roozendaal, K.,Oosterhuis, J.W.Looijenga, L.H., 2007. Further characterization of the first seminoma cell line TCam-2. Genes Chromosomes Cancer.

De Jong, J.,Stoop, J.,Dohle, G.R.,Bangma, C.H.,Kliffen, M.,Van Esser, J.W.J., Van den Bent, M.,Kros, J.M., Oosterhuis, J.W.Looijenga, L.H.J., 2005. Diagnostic value of OCT3/4 for pre-invasive and invasive testicular germ cell tumors. J. Pathol. 206, 242-249.

Donovan, P.J., 1994. Growth factor regulation of mouse primordial germ cell development. Curr Top Dev Biol. 29, 189-225.

Draper, J.S.,Smith, K.,Gokhale, P.,Moore, H.D.,Maltby, E.,Johnson, J.,Meisner, L.,Zwaka, T.P.,Thomson, J.A.Andrews, P.W., 2003. Recurrent gain of chromosomes $17 q$ and 12 in cultured human embryonic stem cells. Nat Biotechnol. 22, 53-54.

Gidekel, S.,Pizov, G.,Bergman, Y.Pikarsky, E., 2003. Oct-3/4 is a dosedependent oncogenic fate determinant. Cancer Cell. 4, 361-370.

Gillis, A.J.,Stoop, H.J.,Hersmus, R.,Oosterhuis, J.W.,Sun, Y.,Chen, C., Guenther, S.,Sherlock, J.,Veltman, I.,Baeten, J.,van der Spek, P.J., de Alarcon, P.Looijenga, L.H., 2007. High-throughput microRNAome analysis in human germ cell tumours. J Pathol. 213, 319-328.

Gondos, B., 1993. Ultrastructure of developing and malignant germ cells. Eur Urol. 23, 68-75.

Gondos, B.,Berthelsen, J.G.Skakkebaek, N.E., 1983. Intratubular germ cell neoplasia (carcinoma in situ): a preinvasive lesion of the testis. Ann Clin Lab Sci. 13, 185-192.

Grumbach, M.M.,Hughes, I.A.Conte, F.A. (2003) Disorders of sex differentiation. IN LARSEN, P.R..,KRONENBERG, H.M..,MELMED, 
S.POLONSKY, K.M. (Eds.) Williams textbook of endocrinology. Philadelphia, W.B. Saunders.

Hajkova, P.,Erhardt, S.,Lane, N.,Haaf, T.,El-Maarri, O.,Reik, W.,Walter, J.Surani, M.A., 2002. Epigenetic reprogramming in mouse primordial germ cells. Mech Dev. 117, 15-23.

Hammes, A.,Guo, J.K.,Lutsch, G.,Leheste, J.R.,Landrock, D.,Ziegler, U.,Gubler, M.C.Schedl, A., 2001. Two splice variants of the Wilms' tumor 1 gene have distinct functions during sex determination and nephron formation. Cell. 106, 319-329.

Hannema, S.E.,Scott, I.S.,Rajpert-De Meyts, E.,Skakkebaek, N.E.,Coleman, N.Hughes, I.A., 2006. Testicular development in the complete androgen insensitivity syndrome. J Pathol. 208, 518-527.

Hawkins, J.R., 1993. Mutational analysis of SRY in XY females. Hum Mutat. 2, 347-350.

Honecker, F.,Stoop, H.,de Krijger, R.R.,Chris Lau, Y.F.,Bokemeyer, C.Looijenga, L.H., 2004. Pathobiological implications of the expression of markers of testicular carcinoma in situ by fetal germ cells. J Pathol. 203, 849-857.

Honecker, F.,Stoop, H.,Mayer, F.,Bokemeyer, C., Castrillon, D.H.,Chris Lau, Y.F.,Looijenga, L.H.J.Oosterhuis, J.W., 2006. Germ cell lineage differentiation in nonseminomatous germ cell tumors. J Pathol. 208, 395-400.

Jacobsen, G.K.,Henriksen, O.B.Van der Maase, H., 1981. Carcinoma in situ of testicular tissue adjacent to malignant germ-cell tumors: a study of 105 cases. Cancer. 47, 2660-2662.

Jørgensen, N.,Muller, J.,Jaubert, F.,Clausen, O.P.Skakkebaek, N.E., 1997. Heterogeneity of gonadoblastoma germ cells: similarities with immature germ cells, spermatogonia and testicular carcinoma in situ cells. Histopathology. 30, 177-186.

Josso, N.,Racine, C.,di Clemente, N.,Rey, R.Xavier, F., 1998. The role of antiMullerian hormone in gonadal development. Mol Cell Endocrinol. 145, 3-7.

Kehler, J., Tolkunova, E.,Koschorz, B.,Pesce, M.,Gentile, L.,Boiani, M.,Lomeli, H.,Nagy, A.,McLaughlin, K.J.,Scholer, H.R.Tomilin, A., 2004. Oct4 is required for primordial germ cell survival. EMBO Rep. 5, 1078-1083.

Kildal, W.,Kraggerud, S.M.,Abeler, V.M.,Heim, S., Trope, C.G.,Kristensen, G.B.,Risberg, B.,Lothe, R.A.Danielsen, H.E., 2003. Genome profiles of bilateral dysgerminomas, a unilateral gonadoblastoma, and a metastasis from a 46, XY phenotypic female. Hum Pathol. 34, 946-949.

Koubova, J.,Menke, D.B.,Zhou, Q.,Capel, B., Griswold, M.D.Page, D.C., 2006. Retinoic acid regulates sex-specific timing of meiotic initiation in mice. Proc Natl Acad Sci U S A. 103, 2474-2479.

Lau, Y.,Chou, P.,lezzoni, J.,Alonzo, J.Komuves, L., 2000. Expression of a candidate gene for the gonadoblastoma locus in gonadoblastoma and testicular seminoma. Cytogenet Cell Genet. 91, 160-164.

Ledford, H., 2007. Doubts raised over stem-cell marker. Nature. 449, 647. Lengner, C.J.,Camargo, F.D.,Hochedlinger, K.,Welstead, G.G.,Zaidi, S.,Gokhale, S.,Scholer, H.R., Tomilin, A.Jaenisch, R., 2007. Oct4 expression is not required for mouse somatic stem cell self-renewal. Cell Stem Cell. 1, 403-415. 
Li, Y.,Tabatabai, Z.L.,Lee, T.L.,Hatakeyama, S.,Ohyama, C.,Chan, W.Y.,Looijenga, L.H.Lau, Y.F., 2007a. The Y-encoded TSPY protein: a significant marker potentially plays a role in the pathogenesis of testicular germ cell tumors. Hum Pathol. 38, 1470-1481.

Li, Y.,Vilain, E.,Conte, F.,Rajpert-De Meyts, E.Lau, Y.F., 2007b. Testisspecific protein $Y$-encoded gene is expressed in early and late stages of gonadoblastoma and testicular carcinoma in situ. Urol Oncol. 25, 141-146.

Liedtke, S.,Enczmann, J.,Waclawczyk, S.,Wernet, P.Kogler, G., 2007. Oct4 and it's pseudogenes confuse stem cell research. Cell Stem Cell. 1, 364-366.

Looijenga, L.H.,Verkerk, A.J.,Dekker, M.C.,van Gurp, R.J.,Gillis, A.J.Oosterhuis, J.W., 1998. Genomic imprinting in testicular germ cell tumours. Apmis. 106, 187-195; discussion 196-187.

Looijenga, L.H.J.,Hersmus, R., Gillis, A.,Stoop, J.,Van Gurp, R.J.L.M.,Veltman, J.,Beverloo, B.,Van Drunen, E.,Geurts van Kessel, A.,Reijo Pera, R.,Schneider, D.T.,Summersgill, B.,Shipley, J.,Mclntyre, A., Van der Spek, P.,Schoenmakers, E.Oosterhuis, J.W., 2006. Genomic and expression profiling of human spermatocytic seminomas;

primary spermatocyte as tumorigenic precursor and DMRT1 as candidate chromosome 9-gene. Cancer Res. 66, 290-302.

Looijenga, L.H.J.Oosterhuis, J.W., 2002. Pathobiology of testicular germ cell tumors: views and news. Analyt Quant Cytol Histol. 24, 263-279.

Looijenga, L.H.J.,Stoop, H.,De Leeuw, P.J.C.,De Gouveia Brazao, C.A., Gillis, A.J.M.,Van Roozendaal, K.E.P.,Van Zoelen, E.J.J.,Weber, R.F.A.,Wolffenbuttel, K.P.,Van Dekken, H.,Honecker, F.,Bokemeyer, C.,Perlman, E.J.,Schneider, D.T.,Kononen, J.,Sauter, G.Oosterhuis, J.W., 2003. POU5F1 (OCT3/4) identifies cells with pluripotent potential in human germ cell tumors. Cancer Res. 63, 2244-2250.

Love, J.D.,DeMartini, S.D.Coppola, C.P., 2006. Prophylactic bilateral salpingo-oopherectomy in a 17-year-old with Frasier syndrome reveals gonadoblastoma and seminoma: a case report. J Pediatr Surg. 41, e14.

Loy, V.Dieckmann, K.P., 1990. Carcinoma in situ of the testis: intratubular germ cell neoplasia or testicular intraepithelial neoplasia? Hum Pathol. 21, 457-458.

McLaren, A., 2003. Primordial germ cells in the mouse. Dev Biol. 262, 1-15.

Møller, H., 1989. Decreased testicular cancer risk in men born in wartime. J Natl Cancer Inst. 81, 1668-1669.

Ogunbiyi, J.O.,Shittu, O.B.,Aghadiuno, P.U.Lawani, J., 1996. Seminoma arising in cryptorchid testes in Nigerian males. East Afr Med J. 73, 129132.

Oosterhuis, J.Looijenga, L., 2005. Testicular germ-cell tumours in a broader perspective. Nat Rev Cancer. 5, 210-222.

Oosterhuis, J.W.,Kersemaekers, A.M.,Jacobsen, G.K.,Timmer, A.,Steyerberg, E.W.,van Weeren, P.C.,Stoop, H.Looijenga, L.H.J., 2003. Morphology of testicular parenchyma adjacent to germ cell tumours; an interim report. APMIS. 111, 32-42. 
Oram, S.W.,Liu, X.X.,Lee, T.L.,Chan, W.Y.Lau, Y.F., 2006. TSPY potentiates cell proliferation and tumorigenesis by promoting cell cycle progression in HeLa and NIH3T3 cells. BMC Cancer. 6, 154.

Ottolenghi, C.,Uda, M.,Crisponi, L.,Omari, S.,Cao, A.,Forabosco, A.Schlessinger, D., 2007. Determination and stability of sex. Bioessays. 29, 15-25.

Ozbun, L.L.,Martinez, A.Jakowlew, S.B., 2005. Differentially expressed nucleolar TGF-beta1 target (DENTT) shows tissue-specific nuclear and cytoplasmic localization and increases TGF-beta1-responsive transcription in primates. Biochim Biophys Acta. 1728, 163-180.

Page, D.C., 1987. Hypothesis: a Y-chromosomal gene causes gonadoblastoma in dysgenetic gonads. Development. 101(Suppl), 151155.

Palmer, S.J.Burgoyne, P.S., 1991. XY follicle cells in the ovaries of $X O / X Y$ and $\mathrm{XO} / \mathrm{XY} / \mathrm{XYY}$ mosaic mice. Development. 111, 1017-1019.

Polanco, J.C.Koopman, P., 2007. Sry and the hesitant beginnings of male development. Dev Biol. 302, 13-24.

Puffenberger, E.G.,Hu-Lince, D.,Parod, J.M.,Craig, D.W.,Dobrin, S.E.,Conway, A.R.,Donarum, E.A.,Strauss, K.A.,Dunckley, T.,Cardenas, J.F.,Melmed, K.R.,Wright, C.A.,Liang, W.,Stafford, P.,Flynn, C.R.,Morton, D.H.Stephan, D.A., 2004. Mapping of sudden infant death with dysgenesis of the testes syndrome (SIDDT) by a SNP genome scan and identification of TSPYL loss of function. Proc Natl Acad Sci U S A. 101, 11689-11694.

Radke, J.R.,Donald, R.G.,Eibs, A.,Jerome, M.E.,Behnke, M.S.,Liberator, P.White, M.W., 2006. Changes in the expression of human cell division autoantigen-1 influence Toxoplasma gondii growth and development. PLoS Pathog. 2, e105.

Raymond, C.S.,Parker, E.D.,Kettlewell, J.R.,Brown, L.G.,Page, D.C.,Kusz, K.,Jaruzelska, J.,Reinberg, Y.,Flejter, W.L.,Bardwell, V.J.,Hirsch, B.Zarkower, D., 1999. A region of human chromosome 9p required for testis development contains two genes related to known sexual regulators. Hum Mol Genet. 8, 989-996.

Reddy, K.S.Sulcova, V., 1998. Pathogenetics of 45,X/46,XY gonadal mosaicism. Cytogenet Cell Genet. 82, 52-57.

Rosenberg, C., Van Gurp, R.J.H.L.M.,Geelen, E.,Oosterhuis, J.W.Looijenga, L.H.J., 2000. Overrepresentation of the short arm of chromosome 12 is related to invasive growth of human testicular seminomas and nonseminomas. Oncogene. 19, 5858-5862.

Rosner, M.H.,Vigano, M.A.,Ozato, K.,Timmons, P.M.,Poirier, F.,Rigby, P.W.Staudt, L.M., 1990. A POU-domain transcription factor in early stem cells and germ cells of the mammalian embryo. Nature. 345, 686692.

Runyan, C.,Schaible, K.,Molyneaux, K.,Wang, Z.,Levin, L.Wylie, C., 2006. Steel factor controls midline cell death of primordial germ cells and is essential for their normal proliferation and migration. Development. 133, 4861-4869.

Schartl, M., 2004. Sex chromosome evolution in non-mammalian vertebrates. Curr Opin Genet Dev. 14, 634-641. 
Schnieders, F.,Dork, T.,Arnemann, J.,Vogel, T.,Werner, M.Schmidtke, J., 1996. Testis-specific protein, Y-encoded (TSPY) expression in testicular tissues. Hum Mol Genet. 5, 1801-1807.

Schumacher, V.et al., Characteristics of testicular dysgenesis syndrome and decreased expression of SRY and SOX9 in Frasier syndrome. Molecular Reproduction and Development. In press.

Skakkebæk, N.E., 1972. Possible carcinoma-in-situ of the testis. Lancet. 516517.

Skakkebaek, N.E.,Rajpert-De Meyts, E.,Jorgensen, N.,Carlsen, E.,Petersen, P.M., Giwercman, A.,Andersen, A.G.,Jensen, T.K.,Andersson, A.M.Muller, J., 1998. Germ cell cancer and disorders of spermatogenesis: an environmental connection? Apmis. 106, 3-11; discussion 12.

Skakkebæk, N.E.,Rajpert-De Meyts, E.Main, K.M., 2001. Testicular dysgenesis syndrome: an increasingly common developmental disorder with environmental aspects. Hum Reprod. 16, 972-978.

Slowikowska-Hilczer, J.,Romer, T.E.Kula, K., 2003. Neoplastic potential of germ cells in relation to disturbances of gonadal organogenesis and changes in karyotype. J Androl. 24, 270-278.

Suarez-Quian, C.A.,Martinez-Garcia, F.,Nistal, M.Regadera, J., 1999. Androgen receptor distribution in adult human testis. J Clin Endocrinol Metab. 84, 350-358.

Summersgill, B.,Osin, P.,Lu, Y.J.,Huddart, R.Shipley, J., 2001. Chromosomal imbalances associated with carcinoma in situ and associated testicular germ cell tumours of adolescents and adults. Brit J Cancer. 85, 213220.

Surani, M.A., 2001. Reprogramming of genome function through epigenetic inheritance. Nature. 414, 122-128.

Swain, A.,Narvaez, V.,Burgoyne, P.,Camerino, G.Lovell-Badge, R., 1998. Dax1 antagonizes Sry action in mammalian sex determination. Nature. 391, 761-767.

Toppari, J.,Kaleva, M.,Virtanen, H.E.,Main, K.M.Skakkebaek, N.E., 2007. Luteinizing hormone in testicular descent. Mol Cell Endocrinol. 269, 3437.

Tu, J.,Fan, L., Tao, K.,Zhu, W.,Li, J.Lu, G., 2007. Stem cell factor affects fate determination of human gonocytes in vitro. Reproduction. 134, 757765.

Ulbright, T.M., 1993. Germ cell neoplasms of the testis. Am J Surg Pathol. 17, 1075-1091.

Veitia, R.A.,Salas-Cortes, L.,Ottolenghi, C.,Pailhoux, E.,Cotinot, C.Fellous, M., 2001. Testis determination in mammals: more questions than answers. Mol Cell Endocrinol. 179, 3-16.

Wagner, S.,Weber, S.,Kleinschmidt, M.A.,Nagata, K.Bauer, U.M., 2006. SETmediated promoter hypoacetylation is a prerequisite for coactivation of the estrogen-responsive pS2 gene by PRMT1. J Biol Chem. 281, 27242-27250.

Wilhelm, D.Koopman, P., 2006. The makings of maleness: towards an integrated view of male sexual development. Nat Rev Genet. 7, 620631. 
Wilhelm, D.,Palmer, S.Koopman, P., 2007. Sex determination and gonadal development in mammals. Physiol Rev. 87, 1-28.

Zangrossi, S.,Marabese, M.,Broggini, M.,Giordano, R.,D'Erasmo, M.,Montelatici, E.,Intini, D.,Neri, A.,Pesce, M.,Rebulla, P.Lazzari, L., 2007. Oct-4 expression in adult human differentiated cells challenges its role as a pure stem cell marker. Stem Cells. 25, 1675-1680. 


\section{Legends to the figures.}

Figure 1. Overview of normal development, level of virilization in DSD patients, precursor lesions and germ cell tumor (GCT) risk. (A) Overview of normal male and female development. The chromosomal sex (XY or XX) determines whether the bipotential gonad (formed under the influence of products of different genes, e.g. WT1, DMRT1) will eventually develop into either a testis (via the SRY/SOX9 pathway) or an ovary (via FOXL2/WNT4). This is predominantly determined by the formation of Sertoli - and granulosa cells, respectively. Initially the earliest developmental stages of the germ cells (PGCs/gonocytes) are positive for OCT3/4. Note that upon physiological maturation of the germ cells, both in the male and female direction, expression of OCT3/4 is lost. The final development of the gonadal sex (testis or ovary) determines the phenotypic male or female characteristics. (B) Relationship between gonadal developmental defect, level of virilization, risk of gonadoblastoma (GB) and/or carcinoma in situ (CIS) formation and GCT risk. The upper panel again represents normal gonadal development (especially in the male direction). The lower panel summarizes different gonadal developmental defects (with an identified genetic basis) related to gonadal differentiation, i.e. level of virilization. In addition, the risk for development of a type II GCT is indicated in the most left column. Note that depending on the level of virilization the precursor lesion presents itself as either GB or CIS.

\section{Figure 2. OCT3/4 and TSPY staining in CIS and GB occurring within a} single DSD gonad. 46, XY DSD (Frasier syndrome) patient presenting with both CIS and GB. (A) OCT3/4 staining in CIS. (B) TSPY staining in same CIS tubule. (C) OCT3/4 staining in GB. (D) TSPY staining in same GB region. Magnification, 100x upper and 400x lower panel, for all (OCT3/4 staining = brown; TSPY staining = red). Slides are counterstained with hematoxilin. 


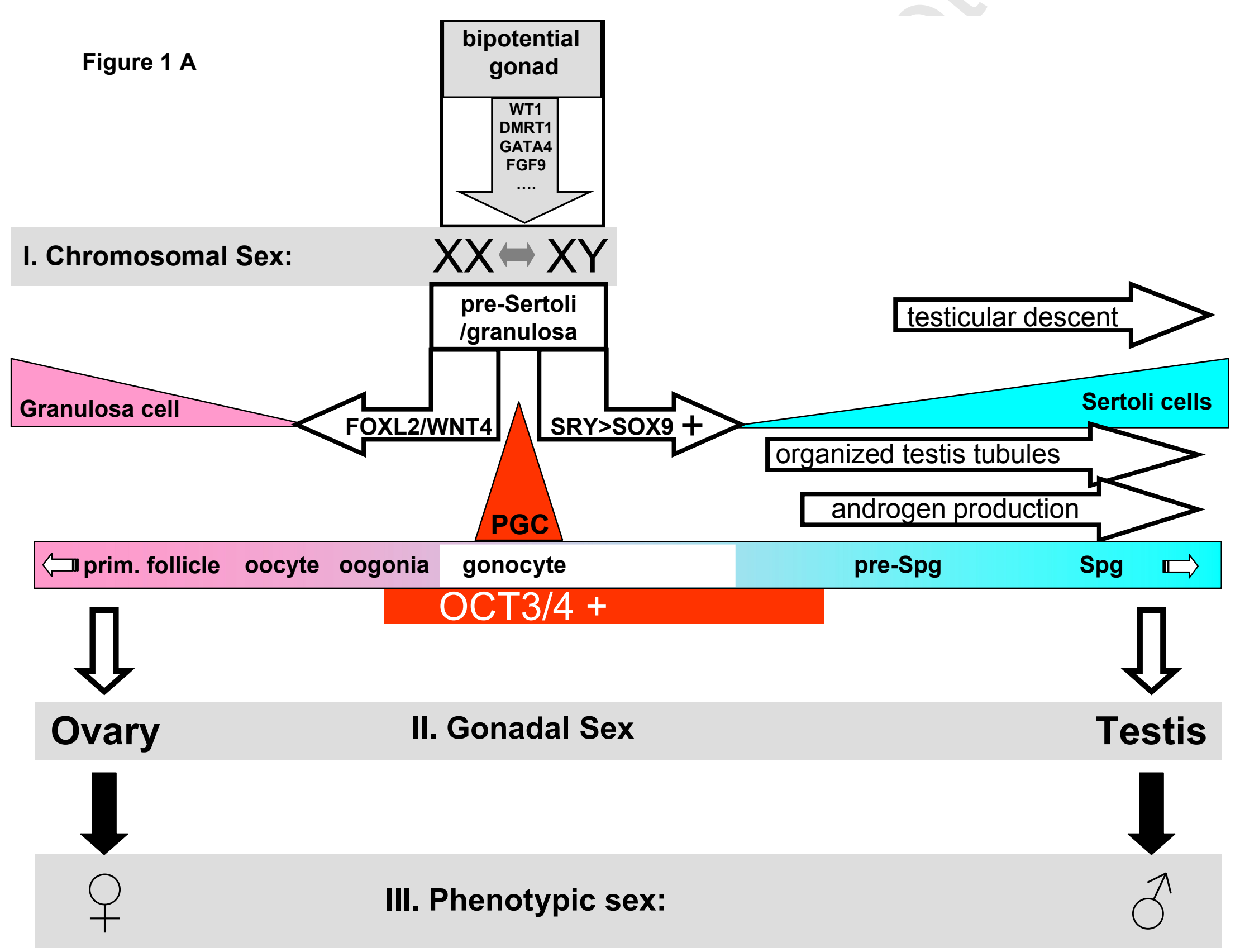




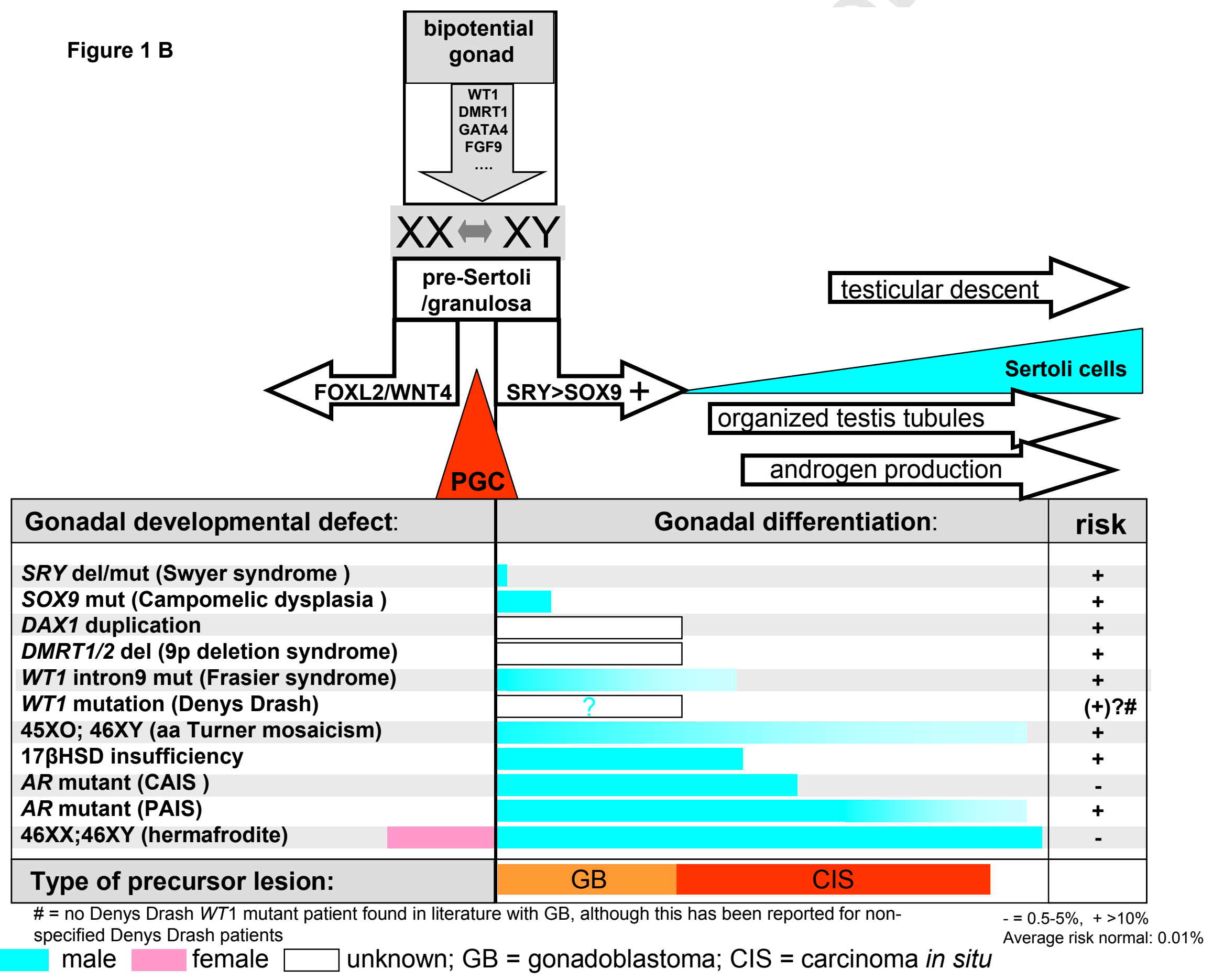


A

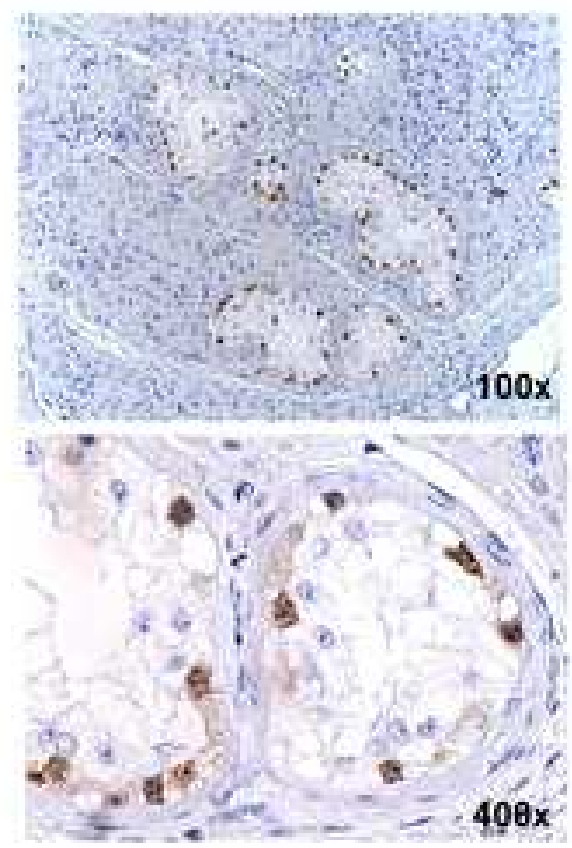

C
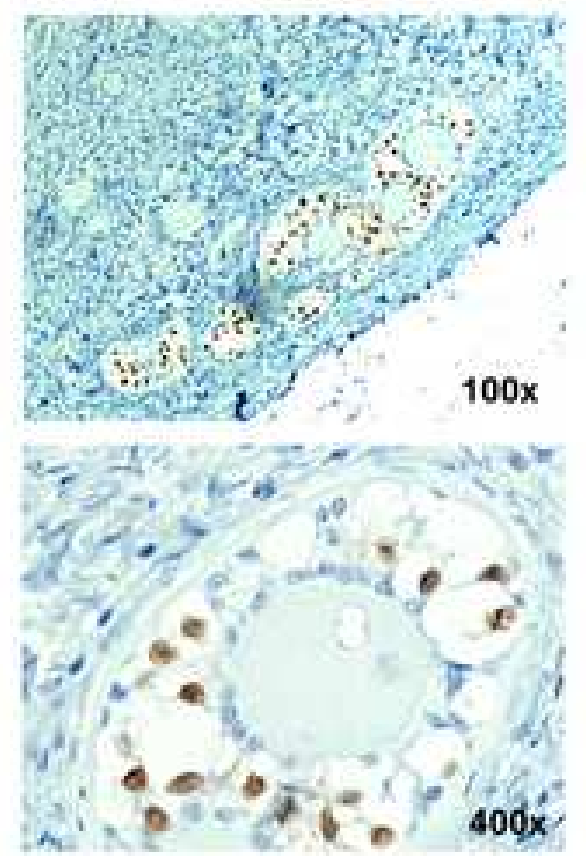

B
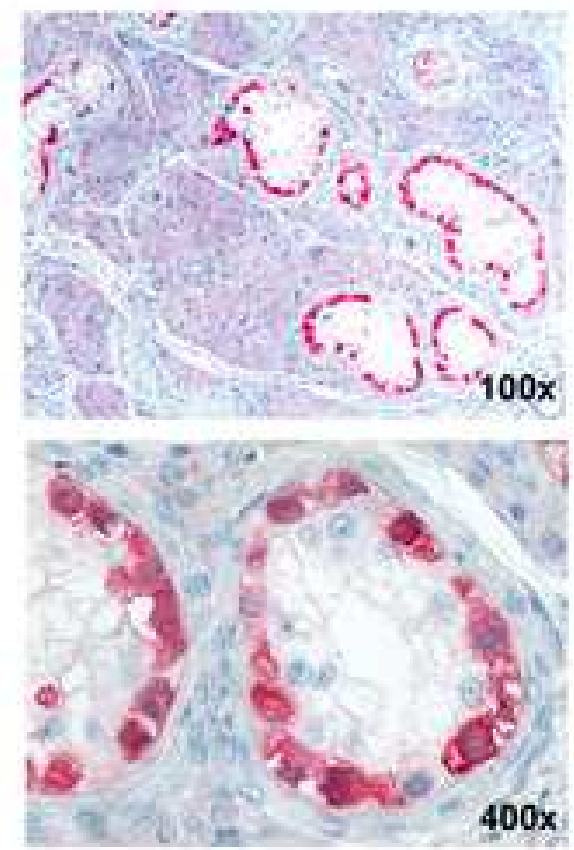

D
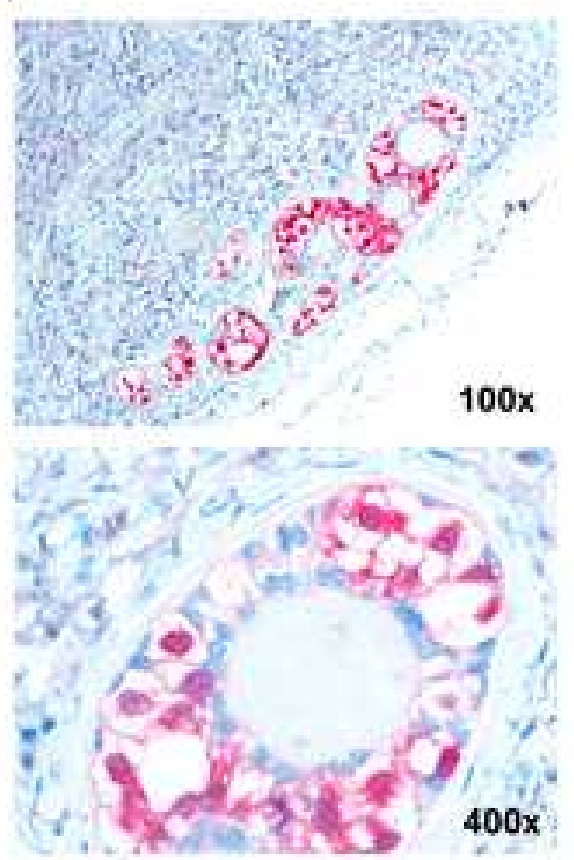
Table 1.

\begin{tabular}{|c|c|c|c|c|c|c|c|}
\hline Type & Anatomical site & Phenotype & Age & $\begin{array}{l}\text { Originating } \\
\text { cell }\end{array}$ & $\begin{array}{l}\text { Genomic } \\
\text { imprinting }\end{array}$ & Genotype & $\begin{array}{l}\text { Animal } \\
\text { model }\end{array}$ \\
\hline 1 & $\begin{array}{l}\text { Testis/ovary/sacral } \\
\text { region/retroperitoneum/ } \\
\text { mediastinum/neck/midline } \\
\text { brain/other rare sites }\end{array}$ & $\begin{array}{l}\text { (Immature) } \\
\text { teratoma/yolk } \\
\text { sac tumor }\end{array}$ & $\begin{array}{l}\text { Neonates } \\
\text { and } \\
\text { children }\end{array}$ & $\begin{array}{l}\text { Early PGC/ } \\
\text { gonocyte }\end{array}$ & $\begin{array}{l}\text { Biparental } \\
\text { partially } \\
\text { erased }\end{array}$ & $\begin{array}{l}\text { Diploid (teratoma) } \\
\text { Aneuploid (yolk-sac tumor): } \\
\text { gain of } 1 q, 12(p 13) \text {, and } \\
20 q, \text { loss of } 1 p, 4 \text {, and } 6 q\end{array}$ & Mouse \\
\hline \multirow[t]{5}{*}{ II } & Testis & $\begin{array}{l}\text { Seminoma/ } \\
\text { non-seminoma }\end{array}$ & $\begin{array}{l}>15 \mathrm{y} \\
\text { (median:35 } \\
\text { and } 25 \mathrm{y} \text { ) }\end{array}$ & $\begin{array}{l}\text { PGC/ } \\
\text { gonocyte }\end{array}$ & Erased & $\begin{array}{l}\text { Aneuploid }(+/ \text { - triploid: gain } \\
\text { of } X, 7,8,12 p \text { and } 21 \text {, loss } \\
\text { of } Y, 1 p, 11,13 \text { and } 18\end{array}$ & Not available \\
\hline & Ovary & $\begin{array}{l}\text { Dysgerminoma/ } \\
\text { non-seminoma }\end{array}$ & $>4 y$ & $\begin{array}{l}\text { PGC/ } \\
\text { gonocyte }\end{array}$ & Erased & Aneuploid/tetraploid & Not available \\
\hline & Dysgenetic gonad & $\begin{array}{l}\text { Dysgerminoma/ } \\
\text { non-seminoma }\end{array}$ & Congenital & $\begin{array}{l}\text { PGC/ } \\
\text { gonocyte }\end{array}$ & Erased & Diploid/tetraploid & Not available \\
\hline & $\begin{array}{l}\text { Anterior mediastinum } \\
\text { (thymus) }\end{array}$ & $\begin{array}{l}\text { Germinoma/ } \\
\text { non-seminoma }\end{array}$ & Adolescents & $\begin{array}{l}\text { PGC/ } \\
\text { gonocyte }\end{array}$ & Erased & Diploid/tri-tetraploid & Not available \\
\hline & $\begin{array}{l}\text { Midline brain (pineal } \\
\text { gland/hypothalamus) }\end{array}$ & $\begin{array}{l}\text { Germinoma/ } \\
\text { non-seminoma }\end{array}$ & $\begin{array}{l}\text { Children } \\
\text { (median } \\
\text { age } 13 \mathrm{y} \text { ) }\end{array}$ & $\begin{array}{l}\text { PGC/ } \\
\text { gonocyte }\end{array}$ & Erased & Diploid/tri-tetraploid & Not available \\
\hline III & Testis & $\begin{array}{l}\text { Spermatocytic } \\
\text { seminoma }\end{array}$ & $>50 y$ & $\begin{array}{l}\text { Spermatogonium/ } \\
\text { spermatocyte }\end{array}$ & $\begin{array}{l}\text { Partially } \\
\text { complete } \\
\text { paternal }\end{array}$ & Aneuploid: gain of 9 & $\begin{array}{l}\text { Canine } \\
\text { seminoma }\end{array}$ \\
\hline IV & Ovary & Dermoid cyst & $\begin{array}{l}\text { Children/ } \\
\text { adults }\end{array}$ & $\begin{array}{l}\text { Oogonia/ } \\
\text { oocyte }\end{array}$ & $\begin{array}{l}\text { Partially } \\
\text { complete } \\
\text { maternal }\end{array}$ & $\begin{array}{l}\text { (Near) diploid, } \\
\text { diploid/tetraploid, peritriploid } \\
\text { (gain of } X, 7,12 \text { and } 15 \text { ) }\end{array}$ & $\begin{array}{l}\text { Mouse } \\
\text { gynogenote }\end{array}$ \\
\hline V & Placenta/uterus & Hydatiform mole & Fertile period & $\begin{array}{l}\text { Empty ovum/ } \\
\text { spermatozoa }\end{array}$ & $\begin{array}{l}\text { Completely } \\
\text { paternal }\end{array}$ & Diploid (XX and $X Y$ ) & $\begin{array}{l}\text { Mouse } \\
\text { androgenote }\end{array}$ \\
\hline
\end{tabular}

y: years; PGC: primordial germ cell 


\section{Table 2.}

\begin{tabular}{|c|c|}
\hline Previous: Intersex & Proposed: Disorders of sex development (DSD) \\
\hline Male pseudohermaphrodite & $46, \mathrm{XY}$ DSD \\
\hline \multicolumn{2}{|l|}{ Undervirilization of an XY male } \\
\hline \multicolumn{2}{|l|}{ Undermasculinization of an $X Y$ male } \\
\hline Female pseudohermaphrodite & $46, \mathrm{XX} D S D$ \\
\hline \multirow{2}{*}{\multicolumn{2}{|c|}{$\begin{array}{l}\text { Overvirilization of an XX female } \\
\text { Masculinization of an XX female }\end{array}$}} \\
\hline & \\
\hline Turner syndrome $(45, \mathrm{X}$ and variants $)$ & Sex chromosome DSD \\
\hline \multicolumn{2}{|l|}{ Klinefelter syndrome $(47, \mathrm{XXY}$ and variants $)$} \\
\hline \multicolumn{2}{|l|}{ Mixed gonadal dysgenesis $(45, \mathrm{X} / 46, \mathrm{XY})$} \\
\hline True hermaphrodite & Ovotesticular DSD \\
\hline $\mathrm{XX}$ male or $\mathrm{XX}$ sex reversal & 46, XX testicular DSD \\
\hline$X Y$ sex reversal & $46, X Y$ complete gonadal dysgenesis \\
\hline
\end{tabular}

